\title{
CD99 Expression in Glioblastoma Molecular Subtypes and Role in Migration and Invasion
}

\author{
Lais C. Cardoso ${ }^{1}$, Roseli da S. Soares ${ }^{1}$, Talita de S. Laurentino ${ }^{1}$, Antonio M. Lerario ${ }^{2}$, \\ Suely K. N. Marie ${ }^{1}$ and Sueli Mieko Oba-Shinjo ${ }^{1, *}$ (D) \\ 1 Laboratory of Molecular and Cellular Biology (LIM 15), Department of Neurology, \\ Faculdade de Medicina FMUSP, Universidade de Sao Paulo, Sao Paulo 01246-903, Brazil; \\ laisccardoso@usp.br (L.C.C.); roselis@usp.br (R.d.S.S.); talitalaurentino@usp.br (T.d.S.L.); \\ sknmarie@usp.br (S.K.N.M.) \\ 2 Department of Internal Medicine, Division of Metabolism, Endocrinology, and Diabetes, \\ University of Michigan, Ann Arbor, MI 48109, USA; alerario@umich.edu \\ * Correspondence: suelimoba@usp.br; Tel.: +55-11-3061-8310
}

Received: 4 February 2019; Accepted: 27 February 2019; Published: 6 March 2019

\begin{abstract}
Glioblastoma (GBM) is the most aggressive type of brain tumor, with an overall survival of 17 months under the current standard of care therapy. CD99, an over-expressed transmembrane protein in several malignancies, has been considered a potential target for immunotherapy. To further understand this potentiality, we analyzed the differential expression of its two isoforms in human astrocytoma specimens, and the CD99 involved signaling pathways in glioma model U87MG cell line. CD99 was also analyzed in GBM molecular subtypes. Whole transcriptomes by RNA-Seq of CD99-siRNA, and functional in vitro assays in CD99-shRNA, that are found in U87MG cells, were performed. Astrocytoma of different malignant grades and U87MG cells only expressed CD99 isoform 1, which was higher in mesenchymal and classical than in proneural GBM subtypes. Genes related to actin dynamics, predominantly to focal adhesion, and lamellipodia/filopodia formation were down-regulated in the transcriptome analysis, when CD99 was silenced. A decrease in tumor cell migration/invasion, and dysfunction of focal adhesion, were observed in functional assays. In addition, a striking morphological change was detected in CD99-silenced U87MG cells, further corroborating CD99 involvement in actin cytoskeleton rearrangement. Inhibiting the overexpressed CD99 may improve resectability and decrease the recurrence rate of GBM by decreasing tumor cells migration and invasion.
\end{abstract}

Keywords: glioblastoma; CD99; migration; cytoskeleton; transcriptome

\section{Introduction}

Glioblastoma (GBM) is the most common malignant brain tumor [1]. The 2016 World Health Organization (WHO) added molecular parameters to histological characteristics to stratify brain tumors [2]; however, only a few molecular targets have shown potential as predictive factors for prognosis or response to therapy [3]. The standard of care with radiotherapy and temozolomide for GBM patients has led to an overall survival period of only 15 to 17 months [4,5]. Such dismal results are due to the highly invasive nature of GBM cells in the normal brain parenchyma, preventing its complete surgical resection and inexorable tumor recurrence [6]. Therefore, new therapeutic approaches for GBM patients are required. The inhibition of constitutively activated signal transduction pathways has demonstrated considerable potential to better control tumor growth [7]. Additionally, immunotherapy has been demonstrated as another approach [8], and CD99, a tumor-associated antigen, is a candidate target for this modality of therapy $[9,10]$. 
In normal cells, the activation of CD99 leads to cell adhesion and migration, homotypic aggregation, apoptosis, expression upregulation, and the transport of various membrane proteins. Moreover, in inflammatory cells, CD99 has been related to Th1 cell differentiation and the activation and proliferation of mature T cells [11,12]. However, CD99 has been implicated as playing dual roles in tumors, as an oncogene (glioma, Ewing's sarcoma, lymphoma/leukemia, melanoma, and breast cancer) or an oncosuppressor (osteosarcoma, Hodgkin's lymphoma, and cancers of the stomach, pancreas, and bladder), as recently reviewed [13]. Additionally, previous microarray expression analyses in gliomas have revealed CD99 among 31 genes coding for membrane proteins potentially targetable for immunotherapy [14]. Nonetheless, the molecular mechanisms involving CD99 are still not fully understood.

CD99 encodes two distinct proteins by alternative splicing [15]. CD99 isoform 1 comprises an extracellular domain glycosylated with O-linked sugar residues, a transmembrane domain and an intracytoplasmic domain with 36 amino acids. CD99 isoform 2 is truncated at the intracytoplasmic domain, presenting only 28 amino acids [12]. CD99 isoforms play distinct functional roles. On B lymphocytes, isoform 1 promotes cell-cell adhesion, while isoform 2 inhibits homotypic adhesion. Both isoforms are required to induce apoptosis in thymocytes and immature T cells [15]. In tumors, such as osteosarcoma, isoform 1 has been described as a potent suppressor of cell migration and invasion, in contrast to isoform 2 , which plays an important role in tumor cell migration and metastatic capacity [16]. Similarly, the CD99 isoform 2 shows the enhanced invasive ability of human breast cancer cells [17].

In the present study, we examined the molecular mechanisms related to CD99 in astrocytomas, especially in GBM, based on human tumor samples and an in vitro cellular model.

\section{Results}

\subsection{CD99 Isoforms Expression in Human Astrocytomas and in U87MG Cell Line}

Striking predominant expression of isoform 1 was observed in different grades of astrocytoma (I-IV) (Figure 1a), and the expression level was higher in astrocytoma samples, compared to that in non-neoplastic (NN) brain tissue, with higher expression in GBM samples. No difference was found in pairwise comparisons of different grades of astrocytoma. The CD99 expression evaluated in 37 classical, 14 mesenchymal, and 14 pro-neural GBM samples from the present cohort [18] showed lower, although not significant, expression in the proneural subtype (Figure 1b). In a larger GBM cohort from The Cancer Genome Atlas (TCGA) database, with 38 classical, 53 mesenchymal, and 29 proneural subtype samples, a significantly higher expression of CD99 in classical and mesenchymal subtypes, than that in proneural subtypes, was observed (Figure 1c). Additionally, the expression analysis of CD99 isoforms, in the U87MG cell line, confirmed the presence of only isoform 1 (Figure 1d), which was also confirmed at the protein level by western blotting with the detection of a unique band of $32 \mathrm{kDa}$ (Figure 1e).

\subsection{Transcriptome Analysis of CD99-siRNA U87MG}

The differential expression analysis of the U87MG knockdown for CD99 and negative non-target control NTC (CD99-siRNA vs. NTC-siRNA) resulted in 2,828 genes, presenting statistical expression differences with adjusted $p \leq 0.01$. CD99 presented the highest fold-change (4.19, corresponding to a 17.51-fold decrease), confirming the efficiency of CD99 gene silencing. The enrichment analysis by DAVID algorithm showed two enriched clusters of functional annotation (Figure 2a), with the first cluster related to cell adhesion. Then, we further investigated the specific genes associated with this cluster encoding membrane, extracellular matrix, stress fiber, focal adhesion, and filopodia/lamellipodia proteins. A heatmap, and the differences in gene expression (fold-change) of these selected genes, are represented in Figure $2 \mathrm{~b}, \mathrm{c}$, respectively. OPN (osteopontin), and LAMA5 (laminin 5) were downregulated, while FN1 (fibronectin 1), THBS1 (thrombospondin 1), and COL6A2 (alpha $(\alpha) 2(\mathrm{VI})$ chain of type VI collagen) were upregulated when CD99 was silenced. The genes 
encoding transmembrane proteins, which interact with extracellular matrix proteins, such as $C D 44$ and some integrin subunits (ITGB8, ITGA2, ITGAV, and ITGA5), were also upregulated.

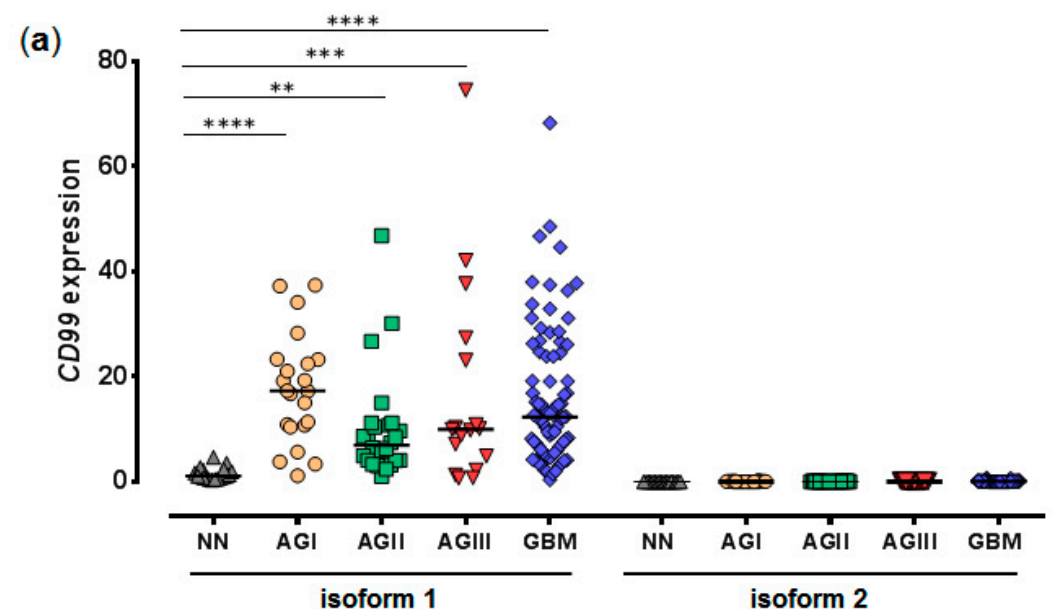

(b)

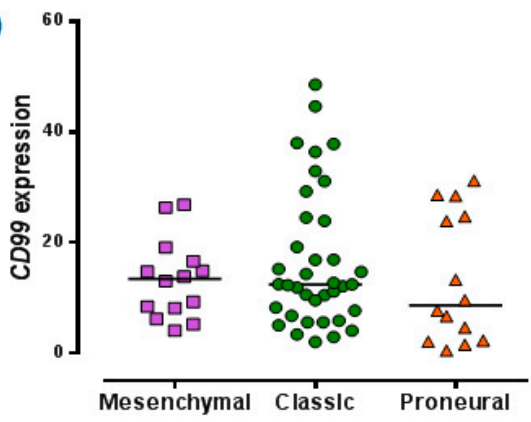

(d)

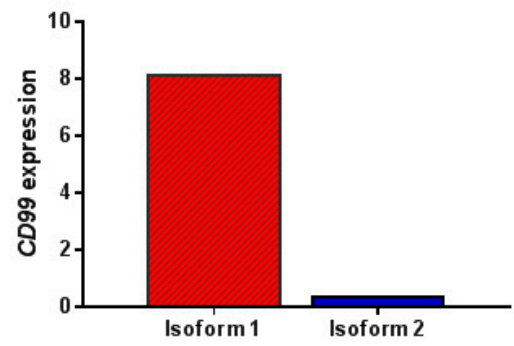

(c)

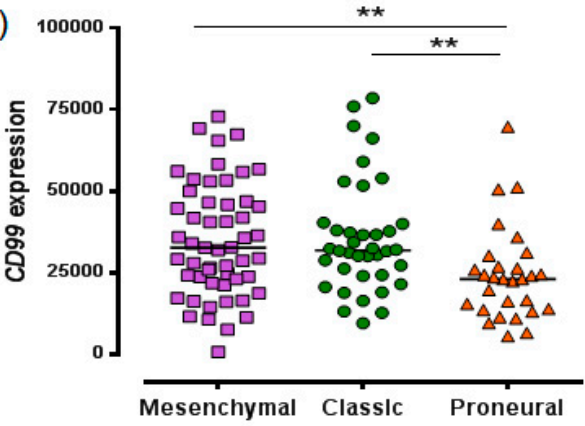

(e)

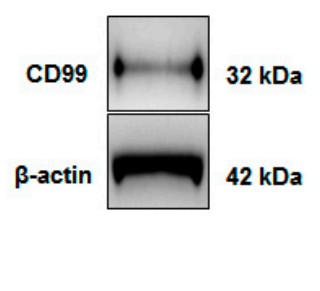

Figure 1. Expression of CD99 in astrocytomas of different malignant grades and the U87MG cell line. (a) Relative quantification of mRNA of CD99 isoforms 1 and 2 in 23 pilocytic astrocytoma (AGI), 26 low-grade astrocytoma (AGII), 17 anaplastic astrocytoma (AGIII), 84 glioblastoma (GBM), and 19 non-neoplastic $(\mathrm{NN})$ tissue samples. The relative expression values were calculated, based on the geometric mean of the HPRT, BCRP, and GUSB housekeeping expression levels of each sample. The differences among the groups were significant $(p<0.0001$, Kruskal-Wallis test). The horizontal bar indicates the median of each group. Asterisks indicate statistical differences: ${ }^{* *} p<0.01,{ }^{* * *} p<0.001$, **** $p<0.0001$, Dunn's test. (b) Isoform 1 CD99 expression levels of GBM molecular subtypes in the present series determined by qRT-PCR and (c) in TCGA database determined by RNA-Seq. Differences among groups were significant $\left(p=0.0031\right.$, Kruskal-Wallis test) for TCGA cases $\left({ }^{* *} p<0.01\right.$ for proneural vs. classic and proneural vs. mesenchymal, Dunn's test). The horizontal bar indicates the median of each group. (d) Relative quantification of mRNA for CD99 isoforms 1 and 2 in glioma cell line U87MG. HPRT was used as a reference gene. The results were expressed as the means of 2 independent experiments. (e) Representative western blot, showing the expression of CD99 in U87MG. $\beta$-actin was used as a control in the experiment. Only one band, corresponding to isoform 1 with $32 \mathrm{kDa}$, was observed. 
(a)

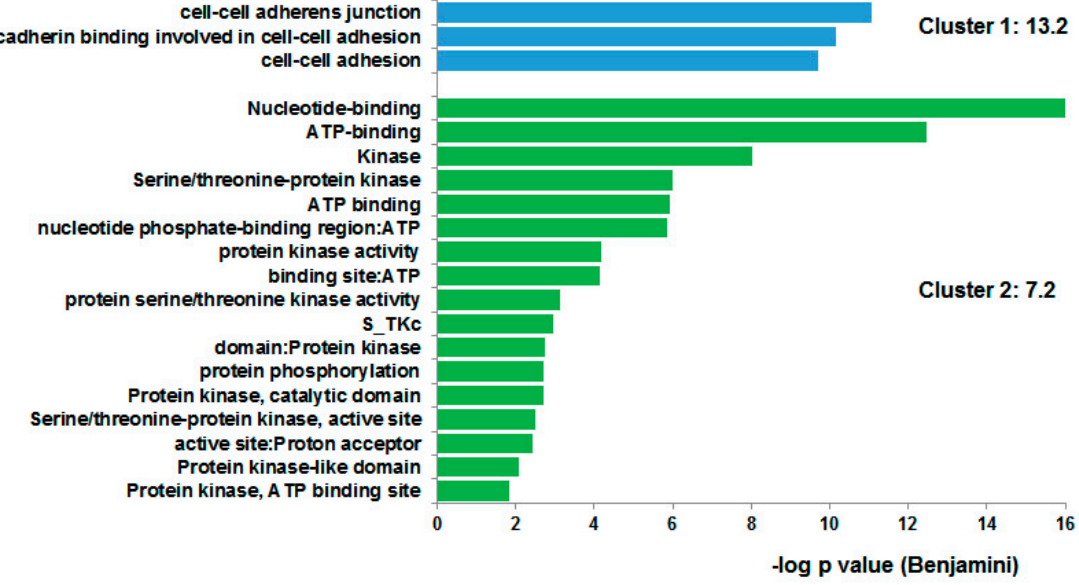

(b)

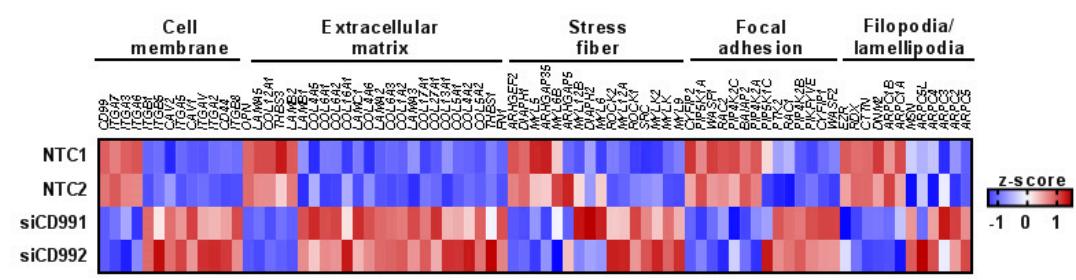

(c)

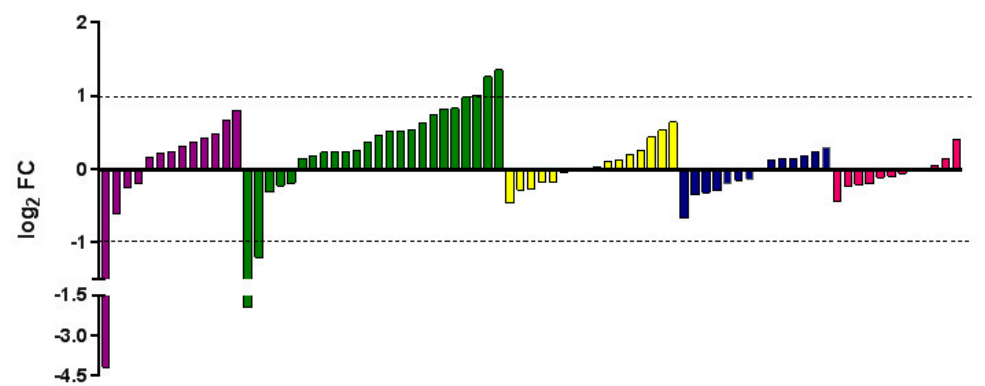

Figure 2. Transcriptome analysis of U87MG cell line knockdown for CD99 by siRNA. (a) The two most enriched functional annotation clusters by the DAVID annotation cluster analysis of differentially expressed genes after CD99 knock down (adjusted $p \leq 0.01$ ). (b) Heatmap representing expression of genes coding for proteins of cell membrane, extracellular matrix, stress fiber, focal adhesion and filopodia/lamellipodia. RPKM values of experimental duplicates were normalized by z-score (c) The $\log _{2}$ fold-change (FC) of genes represented in the heatmap.

\subsection{Functional Analysis of CD99 Involvement in Glioma Cell Migration, Invasion and Adhesion}

CD99-siRNA silencing was transitory, and after 7 days, its gene expression was recovered to approximately $50 \%$ of control NTC (data not shown). Permanent long-term CD99 knockouts were constructed to further study the GBM cell phenotype. The two CD99-shRNA constructs significantly reduced CD99 expression to 20 and 3\% when compared to the control cells (scrambled) (Figure 3a). These results were validated at the protein level by western blotting (Figure $3 b$ ).

The U87MG cell migration after CD99 knockout showed a significant decreased migratory activity compared to that of the controls $(p<0.05)$ (Figure $3 c-e)$ by two image recording methods in a period of 24 h. Particularly, shCD99-2 caused a stronger effect in migration than shCD99-1 (Figure 3c,e). The difference between the two shRNA constructs was evident after $6 \mathrm{~h}$ in the monitored migration assay.

An inhibitory invasion effect of 47\% for shCD99-1 and 45\% for shCD99-2 in relation to scramble was observed ( $p<0.05$ for both analysis) (Figure 4a). The short-term adhesion assay for $3 \mathrm{~h}$ demonstrated the reduced adhesion of shCD99-1, compared to control, in contrast with the increased adhesion of shCD99-2 in relation to control ( $p<0.0001$ for both comparisons) (Figure $4 b$ ). A residual $20 \%$ of CD99 expression in shCD99-1 may explain the opposing findings in this assay. 
(a)
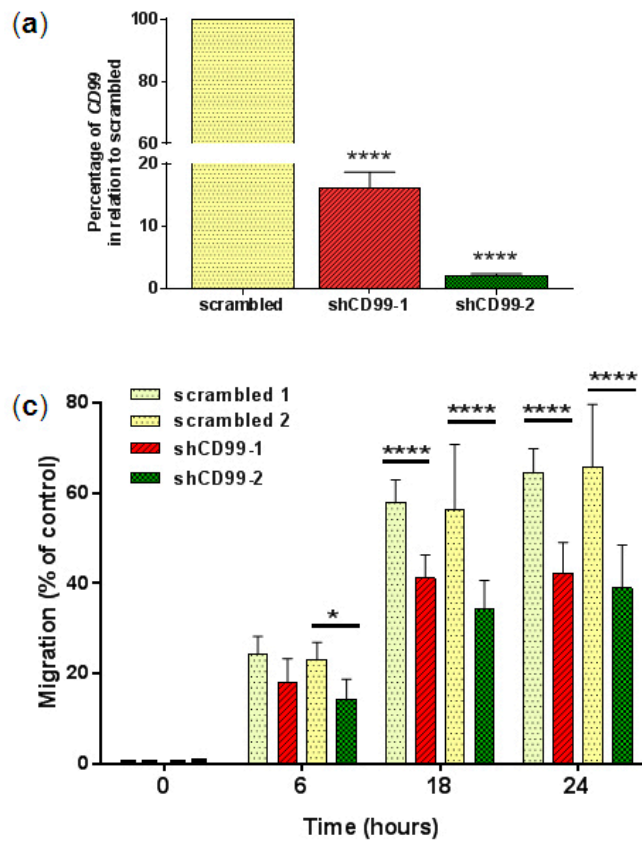

(b)

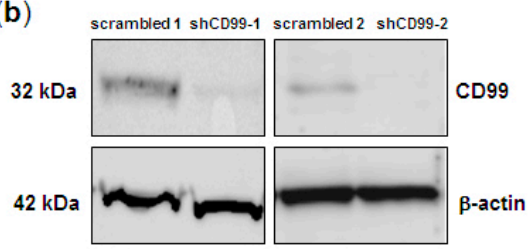

(e)

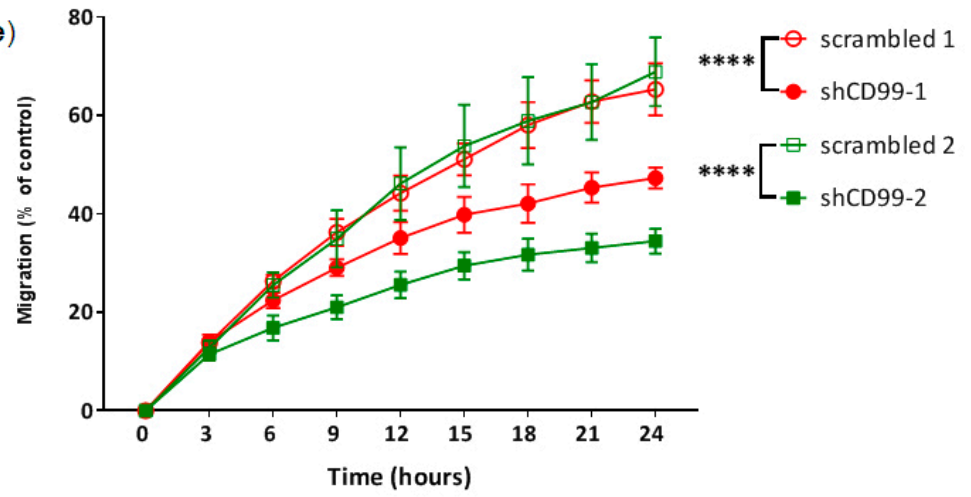

Figure 3. Effects of CD99 knockdown by shRNA on U87MG cell line on migration. (a) Quantification of the mRNA levels in U87MG cells for CD99 knockdown (shRNA) and control (scrambled) for two clones (shCD99-1 and shCD99-2). HPRT was used as a reference gene for the analysis. Graphs represent 3 independent experiments. The asterisks indicate statistically significant differences of shCD99-1 and shCD99-2 and their respective controls ( ${ }^{* * * *} p<0.0001$, Student's $t$ test). (b) Western blot analysis of the CD99 expression in U87MG cell line after transduction with shCD99-1 and shCD99-2 and controls (scrambled). $\beta$-actin was used as control for protein loading. (c) Migration assay, showing that U87MG cells transfected with shCD99-1 and shCD99-2 with reduced migratory activity compared to that of controls. The graph represents the area invaded by cells at $0,6,18$ and $24 \mathrm{~h}$ after scratching. The results were expressed as the means \pm standard deviation (quadruplicates) of two independent experiments. Asterisks indicate statistically significant differences of the CD99 silenced cells in relation to their controls at different times $\left({ }^{*} p<0.05\right.$ and ${ }^{* * *} p<0.0001$, Bonferroni test). (d) Representative photomicrographs of wound closure of U87MG cell line at 0,6, 18, and $24 \mathrm{~h}, 10 \times$ magnification. (e) Real-time migration assay, confirming reduced migration observed each $3 \mathrm{~h}$ for a period of $24 \mathrm{~h}$. U87MG cells knocked down with shCD99-1 (closed circle) and shCD99-2 (closed square) showed reduced migratory activity, when compared to respective controls, scrambled 1 (open circle) and scrambled 2 (open square). The result was expressed as the means \pm standard deviation (sextuplicate). The asterisk indicates statistically significant difference of cells silenced for CD99 in relation to scrambled at different times $(* * * * p<0.0001$; non-linear regression analysis). 
(a)
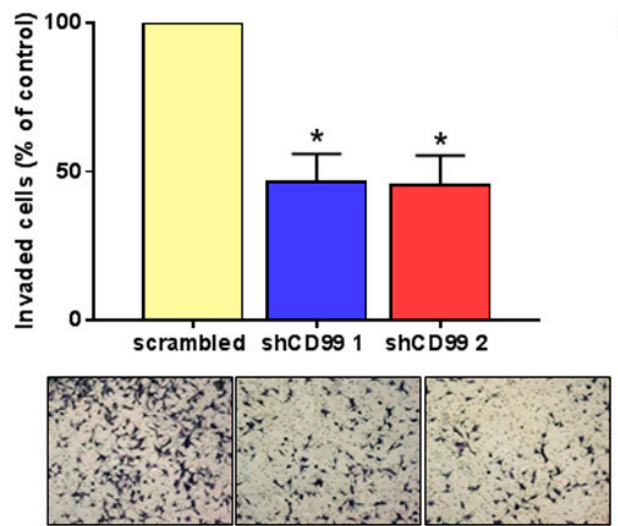

scrambled

shCD99 1

(c)
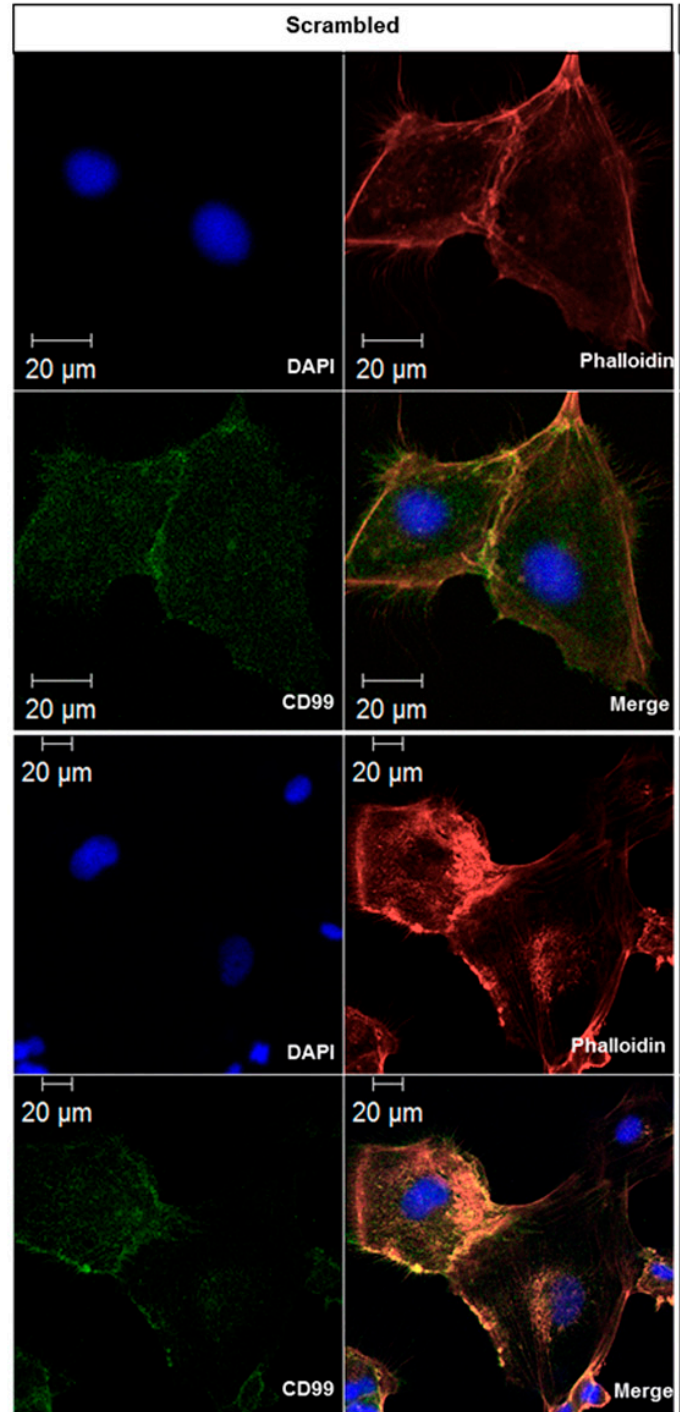

(b)

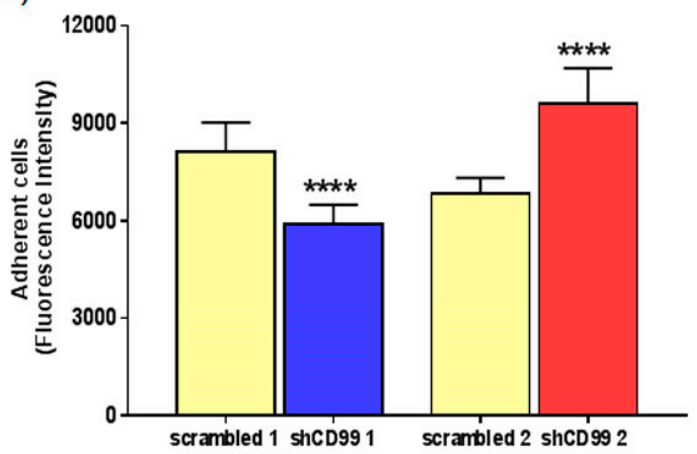

shCD99
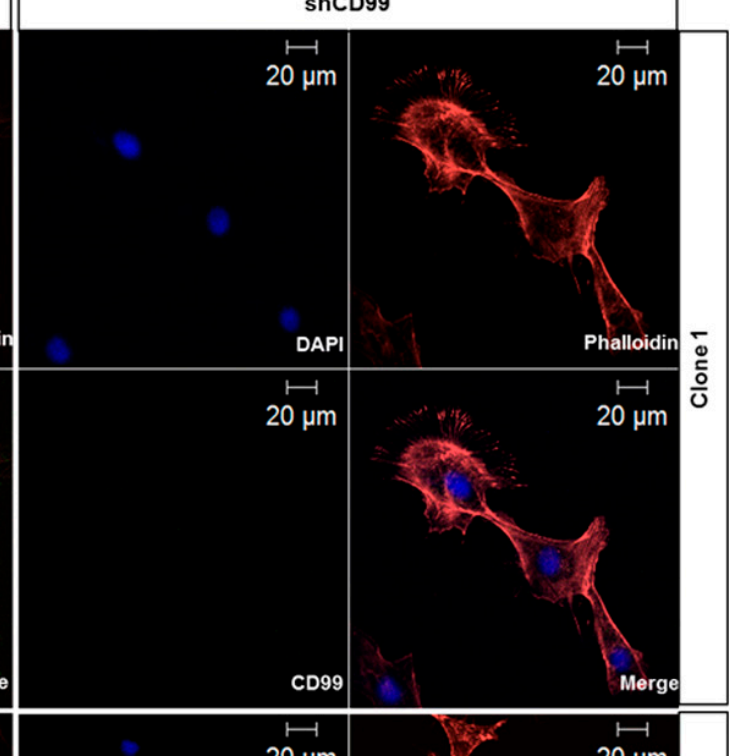

$20 \mu \mathrm{m}$

$20 \mu \mathrm{m}$

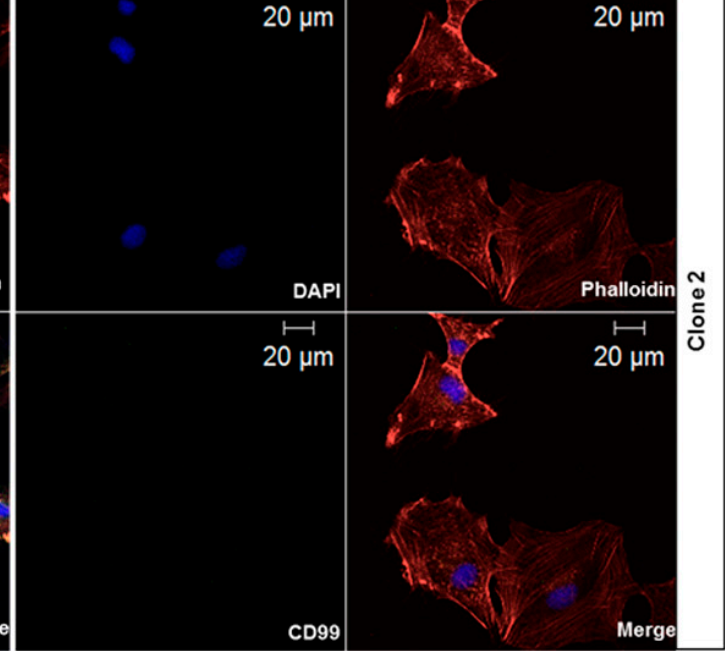

Figure 4. Role of CD99 in invasion and adhesion of the U87MG cell line, and colocalization of CD99 and phalloidin. (a) Trans-well invasion assay showing decreased U87MG invasion after CD99 knockdown (shCD99-1 and 2), when compared to the controls (scrambled). Graph represents percentage of invaded cells in relation to the control (means \pm standard deviations of the means) in two independent experiments conducted in duplicate ( $p<0.05$, Mann-Whitney test). The images show representative fields of U87MG cells that invaded and crossed the inserts (40x magnification). (b) Adhesion assay, with U87MG cells viability measurement by evaluation after $3 \mathrm{~h}$ of cell seeding onto the plate. The shCD99-1 
U87MG cells attached less to the plate, while shCD99-2 U87MG cells attached more compared to its controls. The graph expresses the average of sextuplicate of two independent experiment (**** $p<0.0001$, Mann-Whitney test). (c) Immunofluorescence showing that CD99 (green) and phalloidin (red) colocalize at cell-cell junctions and lamellipodia. Nuclei were stained with DAPI (blue). U87MG cell line knocked down for CD99 and controls. The images were analyzed by confocal microscopy by using a $40 \times$ objective.

\subsection{CD99 Colocalizes with F-Actin}

The colocalization of CD99 with phalloidin was observed in the cell-cell contact regions and in lamellipodia in control U87MG cells, and CD99 expression was not detected in U87MG cells knocked down for CD99, as expected. Interestingly, relevant changes in morphology were observed in both U87MG shCD99-1 and 2 cells, consisting of the altered organization of actin microfilaments and cytoplasmic protrusions compared to the controls. Moreover, actin distribution was more homogeneous in all adherent membrane cells in shCD99-1, while more spaced actin bundles were shown in shCD99-2 (Figure 4c).

\section{Discussion}

CD99 has been described as a highly expressed tumor-associated antigen in GBM tissues and a potential target for synthetic multi-peptide vaccines or dendritic cell immunotherapy [10]. Nonetheless, the functional role of CD99 in tumors has not yet been fully elucidated, and the ligand for CD99 has not yet been identified. Thus far, the current knowledge of CD99 function derives from experiments of CD99 activation by agonist monoclonal antibodies, in hematopoietic and tumor cells [19,20]. In addition, the knowledge of CD99-regulated pathways in the GBM is relatively sparse.

The findings of the present study show that CD99 is a worthwhile target to be explored for therapeutic purposes.

\subsection{Expression of CD99 Isoforms}

CD99 isoform 1 was the predominant isoform present in different malignant grades of human astrocytomas, when compared to NN brain tissue, as observed in other studies [10]. Its expression was particularly higher in GBM, when compared to lower malignant grade diffusely infiltrative astroctyomas [9]. CD99 dual behavior has been reported to be associated with tumor progression in Ewing sarcoma and acute lymphoblastic leukemia [21], as tumor suppressor in osteosarcoma [22], and in Hodgkin's lymphoma [23], which may be attributed to differential preponderance of CD99 isoforms. In fact, CD99 isoform 1 has been reported to regulate lymphocyte adhesion mediated by the integrin LFA-1, in contrast to isoform 2, which is associated with the inhibition of spontaneous adhesion of these cells via the LFA-I/ICAM pathway [24]. In tumors, CD99 isoforms have also been related to different functions in tumor malignancy. In osteosarcoma, isoform 1 acted as a potent suppressant of migration and metastasis through c-Src repression $[15,16]$, while isoform 2-transfected breast cancer cell lines and showed a superior ability to migrate compared to the control, and this difference was not observed in the same cells transfected with the isoform $1[17,25]$. Additionally, and antibody against CD99 induced CD99 engagement and a consequent non apoptotic, caspase-independent programmed cell death of Ewing sarcoma cells, with micropinocytosis by a pathway that resembles methuosis [26]. More recently, a ligand to CD99 extracellular region, clorafabine, inhibited malignant properties of Ewing sarcoma cells, opening new perspectives to target this molecule for cancer therapy [27]. In our GBM model, CD99 isoform 1 proved to be pro-tumorigenic, and therefore the isoform as druggable target. 


\subsection{Transcriptome Analysis and Signaling Pathways Modulated by CD99}

Interestingly, the U87MG CD99-siRNA transcriptome analysis pointed out that the most enriched processes, that are related to the downregulation of $C D 99$, were cell-cell adherent junction and adhesion in accordance with previously reported CD99 roles in tumors. We hypothesize that CD99 may modulate integrin inside-out signaling pathway through the activation of G-protein $\beta / \gamma$ subunit/c-Scr/FAK1/Talin. Talin binds to integrin $\beta 3$ cytoplasmatic tail and induces conformational changes in their extracellular domains, resulting in an increased integrin affinity for ligands [28]. Alternatively, CD99 may activate caveolin-1 via integrin $\alpha \mathrm{V}$ or $\alpha 5$, and caveolin-1 thus activating FAK1. Once FAK1 is activated, vinculin activates $\alpha$-actin promoting cell adhesion and stress fiber formation. Moreover, FAK1 may activate CDC42/RAC that regulates Arp2/3-mediated actin polymerization and consequent orientation of cell migration [29]. Recently, another pathway has been described in a breast cancer model, where CD99-derived agonist ligands inhibit fibronectin-mediated $\beta 1$ integrin activation, through the SHP2/ERK/PTPN12/FAK1 signaling pathway [30]. The suppression of $\beta 1$ integrin activity by CD99 activation may occur through the dephosphorylation of FAK1 at Y397 [31].

Therefore, the present transcriptome data and the findings of previous studies suggest that extracellular matrix targets, together with tumor-associated antigens, including CD99 and integrins, participate in a cytosolic downstream pathway intermediated by FAK1 and c-Src. Actually, the analysis of focal adhesion and regulation of actin cytoskeleton pathways in the present transcriptome data demonstrated the downregulation of RhoGap expression genes (ARHGAP5 and ARHGAP35), DIAPH1, myosin light chain genes (MYL5, MYL6B and MYL12B), related to the stress of fiber formation. Similarly, the downregulation of genes, which code for several targets downstream of FAK1 related to filopodia and lamellipodia formation by actin branch regulation essential for cell migration, such as Rac family small GTPase 2 (RAC2), cytoplasmic FMR1 interacting protein 2 (CYFIP2), WAS protein family member 1 (WASF1), BAI1-associated protein 2 (BAIAP2), and actin-related protein $2 / 3$ complex subunit $1 \mathrm{~A}$ and $1 \mathrm{~B}$ (ARPC1A and ARPC1B) was observed.

Additionally, genes coding ezrin-radixin-moesin (ERM) complex, named EZR, RDX, and MSN, respectively, were downregulated when CD99 was silenced. When the ERM complex is activated, the $\mathrm{N}$-terminal, named FERM domain, binds the actin cytoskeleton to the cell membrane [32]. Therefore, a downregulation of this complex can further disorganize the actin cytoskeleton and consequently prevent cell migration. Similarly, genes coding for dynamin 2 (DNM2) and cortactin (CTTN) were also downregulated with the reduction of CD99 expression. These proteins participate in cell migration by stabilizing F-actin bundles in filopodia [33,34].

\subsection{Influence of CD99 on Migration, Invasion and Cell Adhesion}

The functional assays, with U87MG CD99-shRNA, demonstrated that CD99 downregulation resulted in decreased migration and invasion of tumor cells. GBM cells use a mesenchymal mode of migration and invasion similar to fibroblasts [35,36]. Nonetheless, glioma U87MG cells over-expressing CD99 have presented a higher proportion of amoeboid migration, with high cortical tension and low adhesion to ECM, than that in control cells [37,38].

Decreased cell motility, after CD99 silencing in GBM cells, may be related to dysregulation of stress fiber formation, focal adhesion and particularly to the dysregulation of filopodia and lamellipodia formation, according to the downregulated set of genes identified by the transcriptome analysis (Figure 5). In fact, the overexpression of isoform 1 in osteosarcoma cell lines likewise modulated the expression of genes essential for remodeling the actin cytoskeleton and cell invasion through expression of ARP2 and ARPC1A, which code for proteins of the Arp2/3 complex [16,39]. These previous reports corroborate the present results of the transcriptome analysis. The dysfunction of the Arp2/3 complex is an important node for the regulation of cell motility. 


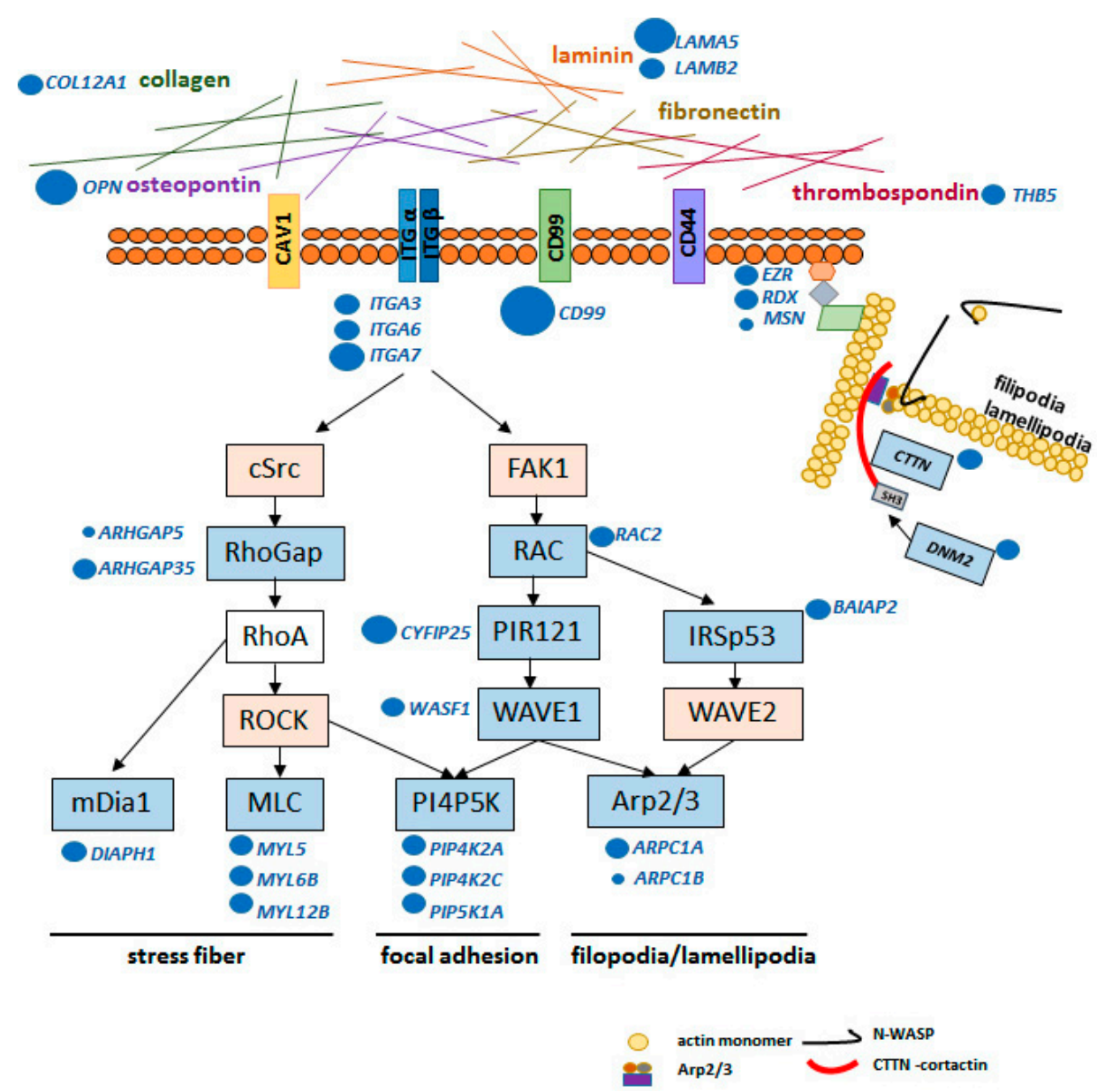

Figure 5. Schematic representation of the focal adhesion and actin regulation of cytoskeleton pathways, showing the plasma membrane and extracellular matrix target, and downstream pathways through c-Src and FAK1 with corresponding intermediate targets involved in stress fiber formation, focal adhesion, filopodia and lamellipodia formation. The gene symbol or the symbol for a group of genes are represented by a blue rectangle when downregulated or an orange rectangle when upregulated, according to the CD99-siRNA U87MG transcriptome analysis. The specific downregulated genes of each group are annotated next to the corresponding rectangle, and the size of blue juxtaposed circles is proportional to RNA-Seq fold change. Below the plasma membrane, on right side, the ERM complex (ezrin-radixin-moesin, coded by $E Z R, R D X$ and $M S C$, respectively) is represented linked to actin polymer, and at the actin branching site, Arp2/3 complex-cortactin (CTTN)-N-WASP—dynamin 2 (DNM2) are represented in lamellipodia and filopodia formation. All components were downregulated when CD99 was silenced, demonstrating their role in the reduction of cell migration.

The functional assays, with U87MG CD99-shRNA, also showed the dysfunction of cell adhesion, suggesting that this function in U87MG cells is dependent on the amount of CD99 expressed in the cells. The complete or near complete knockout of CD99 (98\% knockdown with shCD99-2) presented a higher number of adhered cells in relation to control, in contrast to the prevention of cell adhesion with residual CD99 expression, as observed with shCD99-1 knocked down cells (20\% of residual CD99 expression). The difference may be explained by the proportion of upregulated expression of extracellular matrix components as fibronectin, when CD99 was silenced. In fact, the high concentrations of fibronectin has been related to more abundant, but less dynamic adhesions, whereas low concentrations of fibronection, resulted in few but high dynamic adhesions, and more organized pattern of actin polymerization [40]. The present transcriptome analysis showed highly upregulated expression of fibronection with CD99 silencing, which may explain the loss of cell adherence. Indeed, our immunofluorescence images, co-localized CD99 and phalloidin at the cell-cell contact regions (lamellipodia) of the plasma membrane 
in control U87MG cells, which were strikingly lost in the absence of CD99, leading to the retraction of the cell surface. The small amount of residual CD99, as occurred with shCD99-2 cells, preserved a more spread cell morphology compared to shCD99-1 cells (Figure 4), which may preserve cell adherence through small F-actin bundles in focal adhesion [41,42]. Previous results in Ewing's sarcoma cells, with a CD99 agonist antibody, demonstrated the ability of CD99 to control cell cytoskeleton remodeling and formed adherent junctions and focal adhesions [43], further corroborating the present findings.

\subsection{CD99 Is Upregulated in Glioma Cell Line U87MG}

Interestingly, the TCGA GBM RNA-Seq dataset analysis showed that the most aggressive molecular subtype of GBM, the mesenchymal one, presented the highest expression of CD99. Functional analyses using U87MG, a GBM mesenchymal subtype model, demonstrated that reducing the expression of CD99 decreases migration and invasion of the tumor cells. Therefore, therapeutic strategies to downregulate CD99 may improve tumor respectability and may reduce the probability of tumor recurrence. Further knowledge on the downstream molecular mechanisms, that lead CD99 to modify the cellular actin dynamics, may also enable the identification of other druggable targets for combinatorial therapy and to better improve the outcome of this dreadful tumor.

\section{Materials and Methods}

\subsection{Cell Cultures}

The glioma cell line, U87MG, and the human embryonic kidney cell line, HEK373T, from the American Type Culture Collection (ATCC) were maintained in Dulbecco's Modified Eagle's medium (DMEM) (Thermo Fisher Scientific, Whatham, MA, USA), supplemented with $10 \%$ heat-inactivated fetal bovine serum (FBS) (Thermo Fisher Scientific), antibiotics (100 units $/ \mathrm{mL}$ penicillin, $100 \mu \mathrm{g} / \mathrm{mL}$ streptomycin) in a humidified atmosphere of $5 \% \mathrm{CO}_{2}$ in air at $37^{\circ} \mathrm{C}$. The cell lines were authenticated by short tandem repeat DNA analysis with the commercial GenePrint 10 System (Promega, Fitchburg, WI, USA).

\subsection{Casuistry}

Astrocytoma samples of different grades and non-tumoral brain tissues from epilepsy surgeries were collected during the surgical procedure and immediately frozen in liquid nitrogen after resection by a group at the Division of Neurosurgical of the Department of Neurology, School of Medicine, University of Sao Paulo (HC-FMUSP). A total of 19 NN samples and 150 tumor samples, comprised of 23 AGI, 26 AGII, 17 AGIII and 84 GBMs, were analyzed. The project was approved by the National Ethics Commission (CONEP) and the local institutional ethics committee (numbers 197/2002 and $830 / 2001$, respectively). Post-informed consents were obtained from all patients included in the present study.

\subsection{Total RNA Extraction and cDNA Synthesis}

More than $80 \%$ of tumor tissue was ensured in all tumor samples. The RNeasy Mini Kit (Qiagen, Valencia, CA, USA) was used for total RNA extractions. RNase-free DNase (Qiagen) treatment and quality and concentration assessments were performed. cDNA was obtained by reverse transcription, using SuperScript III reverse transcriptase, RNase inhibitor (RNaseOUT), random oligonucleotides and oligo dT, according to the manufacturer's recommendations (Thermo Fisher Scientific). After treatment with $1 \mathrm{U}$ RNase $\mathrm{H}$ (Thermo Fisher Scientific) at $37^{\circ} \mathrm{C}$ for $30 \mathrm{~min}$ and at $72{ }^{\circ} \mathrm{C}$ for $10 \mathrm{~min}$, cDNA was diluted in Tris-EDTA buffer and stored at $-20^{\circ} \mathrm{C}$ for subsequent analysis.

\subsection{Quantitative Real Time PCR}

CD99 expression levels in tissue samples and cell lines were analyzed by quantitative real time PCR (qRT-PCR) by the SYBR Green method, on ABI 7500 apparatus (Thermo Fisher Scientific). Table 1 
shows the sequences of primers for CD99 isoforms 1 and 2 and reference genes synthesized by IDT (Coralville, IA, USA). All the reactions were performed in triplicate. The final reaction volume of each reaction was $10 \mu \mathrm{L}$, and contained $2.5 \mu \mathrm{L}$ of cDNA, $5 \mu \mathrm{L}$ of Power SYBR Green PCR Master Mix (Thermo Fisher Scientific) and $2.5 \mu \mathrm{L}$ of primers in a pre-standardized concentration. The amplification conditions included an initial incubation at $50{ }^{\circ} \mathrm{C}$ for $5 \mathrm{~min}$ and $95^{\circ} \mathrm{C}$ for $10 \mathrm{~min}$, followed by 40 cycles at $95^{\circ} \mathrm{C}$ for $15 \mathrm{~s}$ and $60^{\circ} \mathrm{C}$ for $60 \mathrm{~s}$. The expression value of $C D 99$ was normalized with reference genes as the internal controls: HPRT, for cell experiments, and HPRT, GUSB, and BCRP, for tissue analyses. For cell analysis, HPRT was used as the reference gene. Single product amplification was confirmed by analyzing its dissociation curve. The amplification efficiencies $\left.\left[\mathrm{E}=10^{(-1 / \text { slope })}-1\right)\right]$ were calculated using serial cDNA dilutions. Equation $2^{-\Delta C t}$ was applied in the calculation of the relative gene expression for efficiency $(E)=100 \pm 10 \%$, where $\Delta C t=[$ mean $C t$ of CD99)] - [mean Ct of HPRT or geometric mean of mean Ct of housekeeping genes] [44].

Table 1. PCR product size and sequence of primers for real time PCR.

\begin{tabular}{|c|c|c|c|}
\hline Gene & PCR Product (bp) & Orientation & Primer $\left(5^{\prime}-3^{\prime}\right)$ \\
\hline \multirow{2}{*}{ CD99 isoform 1} & \multirow[b]{2}{*}{106} & Forward & GATTGTGGGGGCTGTCGT \\
\hline & & Reverse & САССТССССТTGTTCTGCATT \\
\hline \multirow{2}{*}{ CD99 isoform 2} & \multirow{2}{*}{108} & Forward & GATTGTGGGGGCTGTCGT \\
\hline & & Reverse & TCCCTAGGTCTTCAGCCATCATT \\
\hline \multirow{2}{*}{ GUSB } & \multirow{2}{*}{101} & Forward & GAAAATACGTGGTTGGAGAGCTCATT \\
\hline & & Reverse & CCGAGTGAAGATCCСCTTTTTA \\
\hline \multirow{2}{*}{ HPRT } & \multirow{2}{*}{118} & Forward & TGAGGATTTGGAAAGGGTGT \\
\hline & & Reverse & GAGCACACAGAGGGCTACAA \\
\hline \multirow{2}{*}{$B C R P$} & \multirow{2}{*}{67} & Forward & CCTTCGACGTCAATAACAAGGAT \\
\hline & & Reverse & CCTGCGATGGCGTTCAC \\
\hline
\end{tabular}

\subsection{CD99-siRNA and Library Preparations for NGS Sequencing (RNA-Seq)}

CD99 siRNA was performed as previously described in experimental duplicates [9]. The libraries were constructed with the TruSeq Stranded Total RNA kit (Illumina, San Diego, CA, USA) and quantified by qRT-PCR using Kapa Library Quantification Kit (Kapa Biosystems, Wilmington, MA, USA). The mean size of each library was determined on the Tapestation 2200 (Agilent Technologies, San Jose, CA, USA). RNA-Seq sequencing was performed on a HiSeq 2500 (Illumina) sequencer in the SELA Facility Core of School of Medicine, University of Sao Paulo.

\subsection{Transcriptome Analysis}

Sequencing generated an average of 51 million reads per samples. Quality control analysis was performed by FASTQC software. Raw reads were aligned to the hg38 through STAR software [45]. Quantification of the gene expression data was performed through Feature Counts software [46, 47], and the data were normalized according to two different methods: Reads per kilobase million (RPKM) and counts per million (CPM) [48]. Differential expression analysis (bioconductor portal) was analyzed by the Limma-voom framework [49]. The raw data were initially log-transformed and normalized. Subsequently, differential expression between groups was analyzed by linear models and the application of moderate $t$ statistics. This analysis was performed with the RNA-Seq tool [50]. Finally, the analysis of RNA-Seq data (genes differentially expressed in cells silenced by siRNA compared with the NTC) was performed through the DAVID database [51,52] functional and pathway enrichment. RPKM values were transformed to z-scores for heatmap visualization [53]. 


\subsection{TCGA Data Analysis}

The TCGA GBM gene expression from RNA-Seq dataset were downloaded (Genomics Data Commons Data Portal) [54] and normalized by DEseq R software.

\subsection{Construction of Recombinant Lentivirus}

Two CD99 shRNA molecule (MISSION shRNA Library, Sigma-Aldrich, St Louis, MO, USA) sequences were as follows $\left(5^{\prime}-3^{\prime}\right)$ : CCGGGCGCGATAGCGCTAATAATTTCTCGAGAAATTATTAG CGCTATCGCGCTTTTT-3' ${ }^{\prime}$, for control (scrambled), CCGGGCGTTTCAGGTGGAGAAGGAACTCGA GTTCCTTCTCCACCTGAAACGCTTTTTG (shCD99-1), and CCGGCGGATGGTGGTTTCGATTTATCT CGAGATAAATCGAAACCACCATCCGTTTTTG (shCD99-2). The lentivirus transduction particles were prepared by the co-transfection of $2 \times 10^{6}$ HEK293T cells, with $9 \mu \mathrm{g}$ of pCMV-deltaR8.2 containing Gag and Pol genes, $0.9 \mu \mathrm{g}$ of pCMV-VSG-G expressing the G-protein of the vesicular stomatitis, and $9 \mu \mathrm{g}$ of pLKO.1 bearing the shRNAs. For transfection, the reagent FuGENE HD (Promega) was added in antibiotic-free DMEM with 10\% FBS. Lentiviral particles in the culture medium were collected at $48 \mathrm{~h}$ and $72 \mathrm{~h}$, centrifuged, filtered $(0.4 \mu \mathrm{m})$, aliquoted and stored at $-80^{\circ} \mathrm{C}$ until further use.

\subsection{Generation of Knockdown Cell Lines}

A total of $1 \times 10^{5}$ U87MG cells were infected with scrambled 1, scramble 2, shCD99-1 and shCD99-2 with DMEM containing $8 \mu \mathrm{g} / \mathrm{mL}$ of polybrene. At $24 \mathrm{~h}$ after transduction, the supernatant was removed and replaced with culture medium containing puromycin. The CD99 knockdown efficacy was assessed by qRT-PCR and Western blot analyses.

\subsection{Western Blotting}

Cell protein extracts were obtained with urea/Chaps lysis buffer and protease inhibitor cocktail (Sigma-Aldrich). Total protein concentrations were determined by the Pierce BCA Protein Assay Kit (Thermo Fisher Scientific). Cell lysates (30 $\mu \mathrm{g}$ of proteins) were separated by $4-12 \%$ gradient polyacrylamide gel electrophoresis (Thermo Fisher Scientific) in NuPAGE MOPS SDS electrophoresis buffer (Thermo Fisher Scientific) and transferred to a nitrocellulose membrane through the iBLOT system (Thermo Fisher Scientific). The membrane was incubated with mouse monoclonal anti-CD99 (1:1000, DN16, Abcam, Cambridge, MA, USA) and mouse monoclonal anti- $\beta$-actin $(1: 20,000$, clone AC-74, Sigma-Aldrich) as control for protein loading. A secondary antibody anti-mouse IgG (1:1000, Sigma-Aldrich) conjugated to peroxidase and the chemiluminescence detection system (Western Lightning Plus-ECL, Enhanced Chemiluminescence Substrate, Perkin Elmer, Whaltham, MA, USA) were used to visualize proteins in the membrane on the ImageQuant LAS4000 apparatus (GE Healthcare, Pittsburgh, PA, USA).

\subsection{Wound Healing Migration Assay}

A total of $2 \times 10^{5}$ cells/well of silenced cells and their respective controls (scrambled) were grown on 24-well plates, previously coated with Poly-L-Lysine (Sigma-Aldrich), until the cells reached confluence. The culture medium was removed, and a discontinuity cell-free area was formed by scrapping the monolayer with a micropipette tip. Debris were removed by washing with PBS and then replacing it with $2 \mathrm{~mL}$ of fresh medium supplemented with 1\% FBS. Images from three points along each wound were selected and acquired at different time intervals (zero, 6, 12, and $24 \mathrm{~h}$ ). The assays were performed in quadruplicates, and in two independent assays. In parallel, a real-time assay was performed on Axiovert 200M Inverted Motorized Microscope (Carl Zeiss, Jena, Germany) and wound closure was recorded every $3 \mathrm{~h}$ for $24 \mathrm{~h}$. The assay was performed in duplicate, and 3 different fields of each well were photographed. For both experiments, the cell-free areas were initially calculated as a percentage of the initial cell free area (time zero) and arbitrarily labeled 100\%. The percentage of the 
cell free area was calculated by Image [55]. The percentage of migrated area at different times was determined by the difference of the area at time zero (100\%) minus the area free of cells [55].

\subsection{Invasion Assay}

Invasion chambers were used according to the manufacturer's instructions (BD BioCoat Matrigel invasion assay; BD Biosciences, San Jose, CA, USA). U87MG cells (shCD99-1 and 2 and controls) were maintained for $2 \mathrm{~h}$ in DMEM supplemented with $1 \%$ FBS. A total of $2.5 \times 10^{4}$ cells was suspended in $0.5 \mathrm{~mL}$ DMEM, supplemented with $1 \%$ FBS and seeded onto the upper compartment of the Matrigel-coated trans-well inserts fitting the 24-well plates. The bottom chamber was filled with $10 \%$ FBS as a chemo-attractant. Cells were incubated at $37^{\circ} \mathrm{C}$ for $18 \mathrm{~h}$. Non-invading cells were wiped away from the upper surface of the chamber. Invading cells were fixed with $4 \%$ paraformaldehyde, stained with crystal violet $(0.2 \%$ in methanol $20 \%$ ) and analyzed by inverted microscopy with $10 \times$ magnification. The results were quantified by counting all the cells of the inserts in duplicate from two independent experiments. The invasion values were expressed as the percentage of invaded cells in relation to the control.

\subsection{Adhesion Assay}

U87MG shCD99-1, shCD99-2, and controls were incubated for $2 \mathrm{~h}$ in DMEM supplemented with $1 \%$ FBS. A total of $5 \times 10^{4}$ cells were allowed to adhere to 96 -well plates for $3 \mathrm{~h}$ at $37^{\circ} \mathrm{C}$ in $5 \% \mathrm{CO}_{2}$. The cells were gently washed three times with PBS, and attached cells were quantified after incubation with PrestoBlue Cell Viability Reagent (Thermo Fisher Scientific) for $2 \mathrm{~h}$ at $37{ }^{\circ} \mathrm{C}$ in $5 \% \mathrm{CO}_{2}$ in a humidified atmosphere, by measuring the resulting fluorescent signal at $525 \mathrm{~nm}$ by using the GloMax-Multi Microplate Multimode Reader (Promega).

\subsection{Immunofluorescence}

For this analysis, $2 \times 10^{4}$ U87MG cells were plated onto the coverslips, previously coated with Poly-L-Lysine (Sigma-Aldrich) and allowed to attach. After $24 \mathrm{~h}$, the cells were fixed in $4 \%$ paraformaldehyde in PBS for $90 \mathrm{~min}$ at $4^{\circ} \mathrm{C}$. Subsequently, the cells were washed 3 times with PBS for $5 \mathrm{~min}$ and permeabilized with $0.1 \% \mathrm{NP}-40$ (Abcam) in PBS for $30 \mathrm{~min}$ at $37^{\circ} \mathrm{C}$, followed by two washes with PBS for $5 \mathrm{~min}$. Non-specific sites were blocked by incubating cells with $4 \%$ goat serum (Sigma-Aldrich) in PBS (block solution) for $30 \mathrm{~min}$ at $37^{\circ} \mathrm{C}$. The cells were incubated with the primary antibody, anti-CD99, conjugated with FITC (1:50, Thermo Fisher Scientific) and phalloidin labeled with Alexa Fluor 488 (1:50, Thermo Fisher Scientific) diluted in block solution. After incubation for $48 \mathrm{~h}$ at $4{ }^{\circ} \mathrm{C}$, and three washes with PBS for $5 \mathrm{~min}$, the nuclei were counterstained with DAPI (1:1000, Thermo Fisher Scientific) by incubating for $3 \mathrm{~min}$. Finally, the samples were washed 3 times with PBS for $5 \mathrm{~min}$ and embedded with mounting medium ProLong Gold Antifade Mountant (Thermo Fisher Scientific). Negative controls include complete reaction and absence of primary antibody. The documentation and analysis of the slides were performed with the LSM 510 Meta Confocal System (Carl Zeiss).

\subsection{Statistical Analysis}

The normality test of Kolmogorov-Smirnov and Shapiro-Wilk test were applied to analyze the distribution of the CD99 gene expression data by qRT-PCR. Non-parametric Kruskal-Wallis and Dunn's tests were used to analyze the differences in CD99 expression among all groups, between NN and each group of astrocytoma of different grades or between NN and GBM molecular subtypes. The cell data were expressed as the average of the values \pm standard deviation. The Student's $t$ test was used to calculate the statistical significance of CD99 knockdown expression in U87MG cell line in relation to scramble. The wound healing results of cells that were silenced for CD99 and controls were performed by Two-way Anova, followed by post-hoc Bonferroni test. A non-linear regression test was performed for the real-time migration assay to compare groups. For invasion and adhesion assays, comparisons between cells transduced with shCD99-1 and shCD99-2 and respective controls were performed by 
using Mann-Whitney test. For real-time migration assays, non-linear regression analysis was used. Differences were considered statistically significant when $p<0.05$. The calculations were performed using GraphPad Prism v.7.0 (San Diego, CA, USA) and SPSS software, v.15.0 (Chicago, IL, USA).

\section{Conclusions}

In conclusion, the present study showed that isoform 1, of CD99, is exclusively present in human astrocytomas and the U87MG cell line and regulates functions, such as cytoskeleton remodeling, cell migration, invasion, and adhesion. The present transcriptome data of CD99 silenced GBM cells, suggest that CD99 modulates FAK1/c-Src signaling pathways, related to actin cytoskeleton dynamics. The downregulation of this pathway through CD99 knockout, may enable the regulation of the migration and invasion of GBM cells, particularly in the mesenchymal subtype, and may increase the clinical outcome, thereby improving tumor resectability and decreasing the tumor recurrence rate.

Author Contributions: Conceptualization, S.K.N.M. and S.M.O.-S.; Data curation, L.C.C.; Formal analysis, R.d.S.S., A.M.L. and S.M.O.-S.; Investigation, L.C.C., R.d.S.S. and S.K.N.M.; Methodology, L.C.C., R.d.S.S. and T.d.S.L.; Project administration, S.M.O.-S.; Supervision, S.M.O.-S.; Validation, L.C.C. and T.d.S.L.; Visualization, A.M.L.; Writing—original draft, L.C.C.; Writing—review and editing, R.d. S.S., T.d.S.L., A.M.L., S.K.N.M. and S.M.O.-S.

Funding: This research was funded by Sao Paulo Research Foundation (FAPESP), grants 2001/12898-4, 2004/12133-6, 2013/02162-8, 2015/03614-5, and 2015/03995-9, Conselho Nacional de Pesquisa (CNPq), Fundação Faculdade de Medicina (FFM), and Faculdade de Medicina da USP (FMUSP).

Conflicts of Interest: The authors declare no conflict of interest.

\section{Abbreviations}

$\begin{array}{ll}\text { AGI } & \text { Astrocytoma grade I or pilocytic astrocytoma } \\ \text { AGII } & \text { Astrocytoma grade II or low-grade astrocytoma } \\ \text { AGIII } & \text { Astrocytoma grade III or anaplastic astrocytoma } \\ \text { ATCC } & \text { American Type Culture Collection } \\ \text { CPM } & \text { Counts per million } \\ \text { DMEM } & \text { Dulbecco's Modified Eagle's medium } \\ \text { ERM } & \text { Ezrin-radixin-moesin } \\ \text { FAK1 } & \text { Focal adhesion kinase 1 } \\ \text { FBS } & \text { Fetal bovine serum } \\ \text { FERM } & \text { 4.1 and ERM } \\ \text { FC } & \text { Fold change } \\ \text { GBM } & \text { Glioblastoma } \\ \text { GO } & \text { Gene Ontology } \\ \text { NN } & \text { Non-neoplastic } \\ \text { NTC } & \text { Non-target control } \\ \text { RPKM } & \text { Reads per kilobase million } \\ \text { shCD99 } & \text { Short hairpin RNA for CD99 } \\ \text { shRNA } & \text { Short hairpin RNA } \\ \text { siRNA } & \text { Small interfering RNA } \\ \text { TCGA } & \text { The Cancer Genome Atlas } \\ \text { WHO } & \text { World Health Organization }\end{array}$

\section{References}

1. Iacob, G.; Dinca, E.B. Current data and strategy in glioblastoma multiforme. J. Med. Life 2009, 2, $386-393$. [PubMed]

2. Louis, D.N.; Perry, A.; Reifenberger, G.; von Deimling, A.; Figarella-Branger, D.; Cavenee, W.K.; Ohgaki, H.; Wiestler, O.D.; Kleihues, P.; Ellison, D.W. The 2016 World Health Organization Classification of Tumors of the Central Nervous System: A summary. Acta Neuropathol. 2016, 131, 803-820. [CrossRef] [PubMed] 
3. Verhaak, R.G.; Hoadley, K.A.; Purdom, E.; Wang, V.; Qi, Y.; Wilkerson, M.D.; Miller, C.R.; Ding, L.; Golub, T.; Mesirov, J.P.; et al. An integrated genomic analysis identifies clinically relevant subtypes of glioblastoma characterized by abnormalities in PDGFRA, IDH1, EGFR and NF1. Cancer Cell 2010, 17, 98-110. [CrossRef] [PubMed]

4. Keunen, O.; Taxt, T.; Gruner, R.; Lund-Johansen, M.; Tonn, J.C.; Pavlin, T.; Bjerkvig, R.; Niclou, S.P.; Thorsen, F. Multimodal imaging of gliomas in the context of evolving cellular and molecular therapies. Adv. Drug Deliv. Rev. 2014, 76, 98-115. [CrossRef] [PubMed]

5. Soomro, S.H.; Ting, L.R.; Qing, Y.Y.; Ren, M. Molecular biology of glioblastoma: Classification and mutational locations. J. Pak. Med. Assoc. 2017, 67, 1410-1414. [PubMed]

6. Qin, R.; Zhou, J.X.; Chen, C.; Xu, T.; Yan, Y.; Ma, Y.S.; Zheng, Z.L.; Shen, Y.P.; Lu, Y.C.; Fu, D.; et al. LIN28 is involved in glioma carcinogenesis and predicts outcomes of glioblastoma multiforme patients. PLoS ONE 2014, 9, e86446. [CrossRef] [PubMed]

7. Xu, Y.Y.; Gao, P.; Sun, Y.; Duan, Y.R. Development of targeted therapies in treatment of glioblastoma. Cancer Biol. Med. 2015, 12, 223-237. [PubMed]

8. Zhang, J.G.; Kruse, C.A.; Driggers, L.; Hoa, N.; Wisoff, J.; Allen, J.C.; Zagzag, D.; Newcomb, E.W.; Jadus, R. Tumor antigen precursor protein profiles of adult and pediatric brain tumors identify potential targets for immunotherapy. J. Neurooncol. 2008, 88, 65-76. [CrossRef] [PubMed]

9. Urias, U.; Marie, S.K.; Uno, M.; da Silva, R.; Evagelinellis, M.M.; Caballero, O.L.; Stevenson, B.J.; Silva, W.A.; Simpson, A.J.; Oba-Shinjo, S.M. CD99 is upregulated in placenta and astrocytomas with a differential subcellular distribution according to the malignancy stage. J. Neurooncol. 2014, 119, 59-70. [CrossRef] [PubMed]

10. Jung, T.Y.; Choi, Y.D.; Kim, Y.H.; Lee, J.J.; Kim, H.S.; Kim, J.S.; Kim, S.K.; Jung, S.; Cho, D. Immunological characterization of glioblastoma cells for immunotherapy. Anticancer Res. 2013, 33, 2525-2533. [PubMed]

11. Bernard, G.; Raimondi, V.; Alberti, I.; Pourtein, M.; Widjenes, J.; Ticchioni, M.; Bernard, A. CD99 (E2) up-regulates alpha4beta1-dependent $\mathrm{T}$ cell adhesion to inflamed vascular endothelium under flow conditions. Eur. J. Immunol. 2000, 30, 3061-3065. [CrossRef]

12. Hahn, J.H.; Kim, M.K.; Choi, E.Y.; Kim, S.H.; Sohn, H.W.; Ham, D.I.; Chung, D.H.; Kim, T.J.; Lee, W.J.; Park, C.K.; et al. CD99 (MIC2) regulates the LFA-1/ICAM-1-mediated adhesion of lymphocytes, and its gene encodes both positive and negative regulators of cellular adhesion. J. Immunol. 1997, 159, 2250-2258. [PubMed]

13. Manara, M.C.; Pasello, M.; Scotlandi, K. CD99: A Cell Surface Protein with an Oncojanus Role in Tumors. Genes 2018, 9, 159. [CrossRef] [PubMed]

14. Persson, O.; Krogh, M.; Saal, L.H.; Englund, E.; Liu, J.; Parsons, R.; Mandahl, N.; Borg, A.; Widegren, B.; Salford, L.G. Microarray analysis of gliomas reveals chromosomal position-associated gene expression patterns and identifies potential immunotherapy targets. J. Neurooncol. 2007, 85, 11-24. [CrossRef] [PubMed]

15. Alberti, I.; Bernard, G.; Rouquette-Jadanian, A.K.; Pelassy, C.; Pourtein, M.; Aussel, C.; Bernard, A. CD99 isoform expression dictates T-cell functional outcomes. FASEB J. 2002, 16, 1946-1948. [CrossRef] [PubMed]

16. Zucchini, C.; Manara, M.C.; Pinca, R.S.; De Sanctis, P.; Guerzoni, C.; Sciandra, M.; Lollini, P.L.; Cenacchi, G.; Picci, P.; Valvassori, L.; et al. CD99 suppresses osteosarcoma cell migration through inhibition of ROCK2 activity. Oncogene 2014, 33, 1912-1921. [CrossRef] [PubMed]

17. Byun, H.J.; Hong, I.K.; Kim, E.; Jin, Y.J.; Jeoung, D.I.; Hahn, J.H.; Kim, Y.M.; Park, S.H.; Lee, H. A splice variant of CD99 increases motility and MMP-9 expression of human breast cancer cells through the AKT-, ERK-, and JNK-dependent AP-1 activation signaling pathways. J. Biol. Chem. 2006, 281, 34833-34847. [CrossRef] [PubMed]

18. Galatro, T.F.; Sola, P.; Moretti, I.F.; Miura, F.K.; Oba-Shinjo, S.M.; Marie, S.K.; Lerario, A.M. Correlation between molecular features and genetic subtypes of glioblastoma: Critical analysis in 109 cases. Med. Express 2017, 4, M170504. [CrossRef]

19. Hahn, M.J.; Yoon, S.S.; Sohn, H.W.; Song, H.G.; Park, S.H.; Kim, T.J. Differential activation of MAP kinase family members triggered by CD99 engagement. FEBS Lett. 2000, 470, 350-354. [CrossRef]

20. Pasello, M.; Manara, M.C.; Scotlandi, K. CD99 at the crossroads of physiology and pathology. J. Cell Commun. Signal. 2018, 12, 55-68. [CrossRef] [PubMed] 
21. Dworzak, M.N.; Froschl, G.; Printz, D.; De Zen, L.; Gaipa, G.; Ratei, R.; Basso, G.; Biondi, A.; Ludwig, W.D.; Gadner, H. CD99 expression in T-lineage ALL: Implications for flow cytometric detection of minimal residual disease. Leukemia 2004, 18, 703-708. [CrossRef] [PubMed]

22. Sciandra, M.; Marino, M.T.; Manara, M.C.; Guerzoni, C.; Grano, M.; Oranger, A.; Lucarelli, E.; Lollini, P.-L.; Dozza, B.; Pratelli, L.; et al. CD99 drives terminal differentiation of osteosarcoma cells by acting as a spatial regulator of ERK 1/2. J. Bone Miner. Res. 2014, 29, 1295-1309. [CrossRef] [PubMed]

23. Kim, S.H.; Shin, Y.K.; Lee, I.S.; Bae, Y.M.; Sohn, H.W.; Suh, Y.H.; Ree, H.J.; Rowe, M.; Park, S.H. Viral latent membrane protein 1 (LMP-1)-induced CD99 down-regulation in B cells leads to the generation of cells with Hodgkin's and Reed-Sternberg phenotype. Blood 2000, 95, 294-300. [PubMed]

24. Lou, O.; Alcaide, P.; Luscinskas, F.W.; Muller, W.A. CD99 is a key mediator of the transendothelial migration of neutrophils. J. Immunol. 2007, 178, 1136-1143. [CrossRef] [PubMed]

25. Lee, H.J.; Kim, E.; Jee, B.; Hahn, J.H.; Han, K.; Jung, K.C.; Park, S.H.; Lee, H. Functional involvement of src and focal adhesion kinase in a CD99 splice variant-induced motility of human breast cancer cells. Exp. Mol. Med. 2002, 34, 177-183. [CrossRef] [PubMed]

26. Manara, M.C.; Terracciano, M.; Mancarella, C.; Sciandra, M.; Guerzoni, C.; Pasello, M.; Grilli, A.; Zini, N.; Picci, P.; Colombo, M.P.; et al. CD99 triggering induces methuosis of Ewing sarcoma cells through IGF-1R/RAS/Rac1 signaling. Oncotarget 2016, 7, 79925-79942. [CrossRef] [PubMed]

27. Çelik, H.; Sciandra, M.; Flashner, B.; Gelmez, E.; Kayraklioglu, N.; Allegakoen, D.V.; Petro, J.R.; Conn, E.J.; Hour, S.; Han, J.; et al. Clofarabine inhibits Ewing sarcoma growth through a novel molecular mechanism involving direct binding to CD99. Oncogene 2018, 37, 2181-2196.

28. Calderwood, D.A. Integrin activation. J. Cell Sci. 2004, 117, 657-666. [CrossRef] [PubMed]

29. Dayel, M.J.; Mullins, R.D. Activation of Arp2/3 complex: Addition of the first subunit of the new filament by a WASP protein triggers rapid ATP hydrolysis on Arp2. PLoS Biol. 2004, 2, E91. [CrossRef] [PubMed]

30. Lee, K.J.; Kim, Y.; Yoo, Y.H.; Kim, M.S.; Lee, S.H.; Kim, C.G.; Park, K.; Jeoung, D.; Lee, H.; Ko, I.Y.; et al. CD99-Derived Agonist Ligands Inhibit Fibronectin-Induced Activation of $\beta 1$ Integrin through the Protein Kinase A/SHP2/Extracellular Signal-Regulated Kinase/PTPN12/Focal Adhesion Kinase Signaling Pathway. Mol. Cell Biol. 2017, 37, e00675-16. [CrossRef] [PubMed]

31. Lee, K.J.; Yoo, Y.H.; Kim, M.S.; Yadav, B.K.; Kim, Y.; Lim, D.; Hwangbo, C.; Moon, K.W.; Kim, D.; Jeoung, D.; et al. CD99 inhibits CD98-mediated beta 1 integrin signaling through SHP2-mediated FAK dephosphorylation. Exp. Cell Res. 2015, 336, 211-222. [CrossRef] [PubMed]

32. Clucas, J.; Valderrama, F. ERM proteins in cancer progression. J. Cell Sci. 2015, 128, 1253. [CrossRef] [PubMed]

33. Meng, J. Distinct functions of dynamin isoforms in tumorigenesis and their potential as therapeutic targets in cancer. Oncotarget 2017, 8, 41701-41716. [CrossRef] [PubMed]

34. MacGrath, S.M.; Koleske, A.J. Cortactin in cell migration and cancer at a glance. J. Cell Sci. 2012, 125, 1621-1626. [CrossRef] [PubMed]

35. Zhong, J.; Paul, A.; Kellie, S.J.; O'Neill, G.M. Mesenchymal migration as a therapeutic target in glioblastoma. J. Oncol. 2010, 2010, 430142. [CrossRef] [PubMed]

36. Cha, J.; Kang, S.-G.; Kim, P. Strategies of Mesenchymal Invasion of Patient-derived Brain Tumors: Microenvironmental Adaptation. Sci. Rep. 2016, 6, 24912. [CrossRef] [PubMed]

37. Krakhmal, N.V.; Zavyalova, M.V.; Denisov, E.V.; Vtorushin, S.V.; Perelmuter, V.M. Cancer Invasion: Patterns and Mechanisms. Acta Nat. 2015, 7, 17-28.

38. Seol, H.J.; Chang, J.H.; Yamamoto, J.; Romagnuolo, R.; Suh, Y.; Weeks, A.; Agnihotri, S.; Smith, C.A.; Rutka, J.T. Overexpression of CD99 Increases the Migration and Invasiveness of Human Malignant Glioma Cells. Genes Cancer 2012, 3, 535-549. [CrossRef] [PubMed]

39. Scotlandi, K.; Zuntini, M.; Manara, M.C.; Sciandra, M.; Rocchi, A.; Benini, S.; Nicoletti, G.; Bernard, G.; Nanni, P.; Lollini, P.L.; et al. CD99 isoforms dictate opposite functions in tumour malignancy and metastases by activating or repressing c-Src kinase activity. Oncogene 2007, 26, 6604-6618. [CrossRef] [PubMed]

40. Schwartz, M.A.; Horwitz, A.R. Integrating adhesion, protrusion, and contraction during cell migration. Cell 2006, 125, 1223-1225. [CrossRef] [PubMed]

41. DiMilla, P.A.; Barbee, K.; Lauffenburger, D.A. Mathematical model for the effects of adhesion and mechanics on cell migration speed. Biophys. J. 1991, 60, 15-37. [CrossRef] 
42. Palecek, S.P.; Loftus, J.C.; Ginsberg, M.H.; Lauffenburger, D.A.; Horwitz, A.F. Integrin-ligand binding properties govern cell migration speed through cell-substratum adhesiveness. Nature 1997, 385, 537-540. [CrossRef] [PubMed]

43. Chaturvedi, A.; Hoffman, L.M.; Jensen, C.C.; Lin, Y.-C.; Grossmann, A.H.; Randall, R.L.; Lessnic, S.L.; Welm, A.L.; Beckerle, M.C. Molecular dissection of the mechanism by which EWS/FLI expression compromises actin cytoskeletal integrity and cell adhesion in Ewing sarcoma. Mol. Biol. Cell 2014, 25, 2695-2709. [CrossRef] [PubMed]

44. Livak, K.J.; Schmittgen, T.D. Analysis of relative gene expression data using real-time quantitative PCR and the 2(-Delta Delta C(T)) Method. Methods 2001, 25, 402-408. [CrossRef] [PubMed]

45. Dobin, A.; Davis, C.A.; Schlesinger, F.; Drenkow, J.; Zaleski, C.; Jha, S.; Batut, P.; Chaisson, M.; Gingeras, T.R. STAR: Ultrafast universal RNA-seq aligner. Bioinformatics 2013, 29, 15-21. [CrossRef] [PubMed]

46. Li, B.; Dewey, C.N. RSEM: Accurate transcript quantification from RNA-Seq data with or without a reference genome. BMC Bioinform. 2011, 12, 323. [CrossRef] [PubMed]

47. Liao, Y.; Smyth, G.K.; Shi, W. featureCounts: An efficient general purpose program for assigning sequence reads to genomic features. Bioinformatics 2014, 30, 923-930. [CrossRef] [PubMed]

48. Wagner, G.P.; Kin, K.; Lynch, V.J. Measurement of mRNA abundance using RNA-seq data: RPKM measure is inconsistent among samples. Theory Biosci. 2012, 131, 281-285. [CrossRef] [PubMed]

49. Ritchie, M.E.; Phipson, B.; Wu, D.; Hu, Y.; Law, C.W.; Shi, W.; Smyth, G.K. limma powers differential expression analyses for RNA-sequencing and microarray studies. Nucleic Acids Res. 2015, 43, e47. [CrossRef] [PubMed]

50. DeLuca, D.S.; Levin, J.Z.; Sivachenko, A.; Fennell, T.; Nazaire, M.D.; Williams, C.; Reich, M.; Winckler, W.; Getz, G. RNA-SeQC: RNA-seq metrics for quality control and process optimization. Bioinformatics 2012, 28, 1530-1532. [CrossRef] [PubMed]

51. Huang, D.W.; Sherman, B.T.; Lempicki, R.A. Bioinformatics enrichment tools: Paths toward the comprehensive functional analysis of large gene lists. Nucleic Acids Res. 2009, 37, 1-13. [CrossRef] [PubMed]

52. Huang, D.W.; Sherman, B.T.; Lempicki, R.A. Systematic and integrative analysis of large gene lists using DAVID bioinformatics resources. Nat. Protoc. 2009, 4, 44-57. [CrossRef] [PubMed]

53. Huang, D.W.; Sherman, B.T.; Tan, Q.; Collins, J.R.; Alvord, W.G.; Roayaei, J.; Stephens, R.; Baseler, M.W.; Lane, H.C.; Lempicki, R.A. The DAVID Gene Functional Classification Tool: A novel biological module-centric algorithm to functionally analyze large gene lists. Genome Biol. 2007, 8, R183. [CrossRef] [PubMed]

54. Genomica Data Commons Data Portal. Available online: https://portal.gdc.cancer.gov/ (accessed on 9 November 2017).

55. Abramoff, M.D. Image processing with ImageJ. Biophot. Int. 2004, 11, 36-42. 